\begin{tabular}{|l|l|l|}
\hline \multicolumn{2}{|c|}{ PublisherInfo } \\
\hline \hline PublisherName & $:$ & BioMed Central \\
\hline \hline PublisherLocation & $:$ & London \\
\hline \hline PublisherImprintName & $:$ & BioMed Central \\
\hline \hline
\end{tabular}

\title{
Transfecting with antibodies
}

\begin{tabular}{|l|l|l||}
\hline \multicolumn{2}{|c|}{ ArticleInfo } \\
\hline \hline ArticleID & $:$ & 3688 \\
\hline \hline ArticleDOI & $:$ & $10.1186 /$ gb-spotlight-20000523-02 \\
\hline \hline ArticleCitationID & $:$ & spotlight-20000523-02 \\
\hline \hline ArticleSequenceNumber & $:$ & 125 \\
\hline \hline ArticleCategory & $:$ & Research news \\
\hline \hline ArticleFirstPage & $:$ & 1 \\
\hline \hline ArticleLastPage & $:$ & 2 \\
\hline \hline & & RegistrationDate : 2000-05-23 \\
ArticleHistory & $:$ & OnlineDate $\quad 2000-05-23$ \\
\hline \hline ArticleCopyright & $:$ & BioMed Central Ltd2000 \\
\hline \hline ArticleGrants & $:$ & \\
\hline \hline ArticleContext & $:$ & 130591111 \\
\hline \hline
\end{tabular}




\section{William Wells}

Email: wells@biotext.com

The various available transfection methods suffer from low efficiency, lack of specificity for a particular cell type, and a tendency to kill many of the target cells. Bildirici et al. offer a solution in the 18 May Nature, using antibody-coated beads (Nature 2000, 405:298). DNA enters the cells after agitation of a bead-cell mixture tears holes in the cell membrane. Transfection efficiency ranges from 40 to $80 \%$ with less than $20 \%$ cell killing, and the DNA is targeted to cells with the relevant cell surface marker. This targeting will be particularly important for ex vivo gene therapy applications.

\section{References}

1. Nature magazine, [http://www.nature.com/nature/]

This PDF file was created after publication. 